\title{
A jogalkotás és a jogalkalmazás torzulásának világjelensége és az ahhoz vezetô okok
}

\section{Distortion in Legislation and in the Application of Law as a Global Phenomenon and its Causes}

\begin{abstract}
Összefoglalás
A tanulmány a világ uralkodó jogrendszereit bemutatva vázolja fel, mi jellemzi az egyes jogrendszerekben a pozitív jogot, a jogalkotást, valamint a jogalkalmazást és abban a bírói gyakorlatot. Kimutatja, hogy az egyes jogrendszerekben milyen a pozitív jogtól függố bírói jogalkalmazás, esetjogtól vagy tételes jogtól függố-e. Ezzel összefüggésben a szerzô megvizsgálja, hogy a globális pénzügyi és gazdasági érdekeket kiszolgáló jogpolitika a globális célkitûzések szolgálatában miként igyekszik az Európai Bizottságon, az Európai Bíróságon keresztül deformálni az európai államokban a jogalkotást és a jogalkalmazást.
\end{abstract}

Kulcsszavak: aktushozatal, amerikai jog, angolszász jog, bírói gyakorlat, érdekegyeztetés, érzékenyítés, esetjog, Európai Bíróság, jogalkotás, jogalkalmazás, kontinentális európai joganalógia, szokásjog, tételes jog

\section{Summary}

The study outlines the prevailing legal systems of the world and the characteristics of each legal system in a breakdown by positive law, legislation and the application of law, and more specifically, judicial practice. It describes the application of positive jurisdictional law in certain jurisdictions, whether it depends on case law or positive

Prof. Dr. Prugberger Tamás DSc, professor emeritus, Miskolci Egyetem (prugberger.tamas@t-online.hu). 
law. In this context, the author examines the way legal policy seeks, in the service of global financial and economic interests, to distort legislation and law enforcement in European states in the service of global objectives through the European Commission and the Court of Justice of the European Union.

Keywords: American law, Anglo-Saxon law, judicial practice, conciliation, sensitization, case law, European court, legislation, application of law, continental European legal analogy, case law, positive law

A 19. század utolsó harmadára az európai és a transzatlanti civilizált államok jogrendszerei két nagy csoportot alkotva alakultak ki. Az egyik csoport az, amely a kontinentális Európában alakult ki, a másik pedig az angolszász jogrendszer. A kontinentális jogrendszeren belül az egyik alcsoportot a frankofón-latin, míg a másikat a germán jogrendszercsoport képezi. Az angolszász jogrendszer szintén két csoportra tagozódik, melyek közül az egyik a szigetországi brit, vagyis az angol jogrendszer, míg a másik az Amerikai Egyesült Államokra jellemzó transzatlanti jogrendszer (Badó, 2012:28-39; Radics-Bencze, 2012; David, 1977:18, 287-360. pontok; Badó-Bóka, 2012). Tételes jogilag és a jogalkalmazás tekintetében élesen elválva az angolszász jogrendszertól, a frankofón-latin és a germán jogrendszer kizárólagossága volt jellemzô a kontinentális Európa országaira, és tulajdonképpen még ma is ez a jellemzô. Ugyanakkor a kontinentális Európára jellemzô e két jogrendszer közül Skócia joga inkább a kontinentális frankofón jogot érzi magáénak, és ez vonatkozik Kanada francia nyelvú autonóm területére, Québecre is. Ezenkívül az USA egy államában, Louisianában ugyancsak a frankofón jogrendszer érvényesül (Radics-Bencze, 2012:56-57, 68-70). Az így kialakult helyzet állt fenn egészen a 20. század végéig, azzal a különbséggel, hogy Ázsia azon országaiban, mindenekelőtt Törökországban, Kínában és Japánban, ahol német jogtudósok kodifikáltak, a második világháború után a germán jogot kiszorította az angol, és ugyanígy néhány távol-keleti volt francia gyarmatról is kiszorította a frankofón jogrendszert a transzatlanti angolszász jogrendszer, vagyis az USA joga. A fố vonás azonban ma is az, hogy a kontinentális Európában a frankofón-latin és a germán jogrendszer a domináns, némi brit angolszász befolyással a holland és a skandináv államok jogrendszerére, míg az Európához tartozó atlanti-óceáni szigeteken, Anglia és Írország esetében az „ortodox” angolszász jogrendszer (David, 1977, 18. pont), az USA esetében pedig egy „neológ” angolszász jogrendszer van érvényben (Badó-Bóka, 2012:77-81; David, 1977, 366-370. pontok). A két jogrendszer, pontosabban jogrendszercsoport között az alapvetô különbség, hogy míg a kontinentális jogrendszerekre, mind a frankofón-latin, mind a germán jogrendszerekre az jellemzó, hogy a jogalkotás és a jogalkalmazás élesen elválik egymástól, ezzel szemben az angolszász jogrendszereknél a kettô között nincsen határvonal, összefolyik egymással.

A kontinentális jogrendszerekben, tartozzanak azok a frankofón-latin vagy a germán jogrendszercsoporthoz, a jogalkotás szervei, a törvényalkotásra hivatott par- 
Prugberger Tamás: A jogalkotás és a jogalkalmazás torzulásának világjelensége...

lament és a rendeletalkotást végzô miniszterelnök, a minisztériumok és egyéb erre feljogosított központi szakigazgatási szervek, valamint a helyhatóságok mint alaki jogforrások teljesen elkülönülnek a bíróságoktól és azok ítélethozatali tevékenységétôl. A bíróságok ítélethozatali tevékenysége, vagyis az általuk meghozott eseti normák az alaki jogforrásoktól teljesen függetlenek, és csak az általuk meghozott anyagi jogforrásoktól mint általános normáktól függnek, amelyet az eseti ügyek elbírálása során alkalmazniuk kell. A bíró csak az alaki jogforrás által megalkotott anyagi jogforrástól függ, azonban hogy ezt miként alkalmazza, az már a jogszabályban megállapított keretek között az ô belátásától függ. A bírói jogalkalmazás és a jogalkotás alaki jogilag teljesen elkülönül egymástól, és csak anyagi jogilag van bizonyos összefüggés a kettố között, nevezetesen abban, hogy a jogszabály, vagyis a pozitív jog által megadott keretek között állapíthatja meg a bíró az ítélete lényegét jelentô jogkövetkezményt. Ez a jogalkotást a jogalkalmazástól elválasztó cezúra csak annyiban relativizálódik a közigazgatási jogalkalmazás esetében, ha jogszabályalkotásra feljogosított felettes közigazgatási szervnek alárendelt, kifejezetten csak közigazgatási jogalkalmazásra hatáskörrel rendelkezó szerv alkalmazza azt az anyagi jogforrást, amelyet alaki jogforrásként a felettes szerve alkotott meg. Itt is azonban a szervezetileg a közigazgatási alaki jogforrásnak alárendelt közigazgatási jogalkalmazó a jogkövetkezményt csak a jogszabály által meghatározott keretek között állapíthatja meg. A szervezeti függőségből eredố esetleges pszichés jogalkalmazási befolyást azonban tárgyilagossá tudja tenni a közigazgatástól független közigazgatási bírósági jogalkalmazás jogorvoslati jellegú ítélethozatali tevékenysége. Fơszabályként tehát a kontinentális jogrendszerben a jogalkotás és a jogalkalmazás a klasszikus értelmezés tekintetében szigorúan elválik egymástól, ami a szovjet-orosz és a második világháború után a befolyási övezete alá került közép- és kelet-európai államokban sem volt másként. Ugyanakkor a pozitív jog egész dogmatikai rendszerének a gyökere történetileg a kialakult szokáson és a római jogon nyugszik, amely kezdetben a judikatúrában, vagyis a joggyakorlatban a közerkölcs, az ismételt szokáskövetés, és az így kialakult íratlan, majd leírt szokásnormarendszeren, valamint a kezdetben szintén íratlan, majd leírt hatalom- és közösségirányítási normarendszeren nyugodott (David, 1977, 38-44. és 76-80. pontok; Kilic-Paksy, 2012; Peschka, 1975:361-374; 1980, 1. rész, 2. fej.). ${ }^{1}$ Az így kialakult normaszokásrendszer elméleti jogászi rendszerezett absztrakciója vezetett a kodifikációhoz, ami a frankofón-latin jogrendszerekben az ipar és a kereskedelem, valamint a pénzforgalom gyors kifejlódése miatt korábban kodifikálódott, mint a germán jogrendszerekben, ahol az agrárium játszotta a fóbb szerepet (David, 1977, 28-54. pontok; Mezei, 2012:133; Horváth et al., é. n.; Niederhauser, 1965:655. s köv. o.; Prugberger, 1978:19. s köv. o.).

Ezzel szemben az angolszász jogrendszerekben nem az összefüggó normatisztelet és annak alávetett jogalkalmazás játszotta és játssza ma is a fốszerepet, hanem az „act”, vagyis az aktus. Kétféle aktus van, amely minôsíti a konkrét tényállást. Az egyik aktus, amellyel a felperes az alperessel szemben vagy a vádhatóság a vádlottal szemben hoz fel, a másik aktus, amely során a bíró a felek „támadó aktus” és „contra act” mérlegelése alapján meghozza azt az „ítéleti (döntési) aktust”, amely a jogkövetkezményt, a szankciót tartalmazza. Az ítélkezésben iránytúként csak egészen háttérként jelenik 
meg a szokásjogilag kialakult, többnyire nem leírt normarendszer, és az elméletileg kimunkált szokáson alapuló, de az állam által nem megerôsített jogrendszer. Ugyanis a jogalkalmazó elé került aktusban szereplő hasonló tényállásban hozott korábbi ítéletek közül válogat a bíró, amelyek közül kiválasztja azt a legközelebbit, amely legjobban hasonlít ahhoz az aktussal, vagyis keresettel hozzá került ügyhöz, és arra hivatkozva hozza meg az eléje került ügyben az ítéletet, és állapítja meg annak jogkövetkezményét, vagyis a szankciót (Badó, 2012:22.; Eörsi, 1975:118. s köv. o., 130-166). Ilyen elhíresült esetként közli Eörsi Gyula azt az esetet, amikor a gépkocsivezetô elvesztve uralmát az általa vezetett gépkocsin, egy üzlet kirakatában állt meg, a kirakatban lévô árukat tönkretéve. A bíró az ügyben a saját ítéletét egy évszázaddal korábbi ítélet jogkövetkezményét alkalmazva hozta meg, ahol az volt a tényállás, hogy egy lovas kocsi lovai bokrosodtak meg, és belerohantak a piacon a kofák áruiba, tetemes károkat okozva (Eörsi, 1975).

A perben a bíró passzív. A felek ügyvédei, büntetôügyben a vádhatóság és az ügyvéd keresik ki a jogtárból az adott ügyhöz hasonlító korábbi ítéleteket, amelyek közül a bíró a saját meggyôződése alapján választja ki azt az ügyet, amely szerinte a legjobban hasonlít az elôtte fekvô ügyhöz. Az ítélethozatali választását köteles elméletileg a szakirodalom által is alátámasztani, mely ítélet a tudományosan megalapozott indokolással együtt az eljárt bíróság évkönyvében az ítéletet meghozó bíró neve alatt jelenik meg. Ezért lényegileg minden ítélet tudományos közleménynek számít (Badó, 2012:29-39). A klasszikus angolszász jogban a pozitív jog csak mint „tradíció” hat, a bíró alkotta esetjog a domináns. Ebből adódik, hogy az ügyvédek a saját jogi okfejtésük alapján igyekeznek meggyốzni a bírákat, és ezért az alaki jog sokkal rugalmasabb az angolszász „esetjogban” (case law). Mivel ily módon a jogalkotás és a jogalkalmazás összecsúszik, a bírói függetlenség rugalmasabban értelmezhetố az angolszász jogban, mint a kontinentális jogban, és ezért a kijárás is jobban megengedett. Ezzel függ össze az is, hogy az angolszász jogban nincs külön alkotmánybíróság, és ezért az alkotmánybíróság szerepét, eltérve a kontinentális jogrendszerektől, a Legfelsôbb Bíróság látja el. Ezzel szemben, a kontinentális államokban az alkotmánybíróság, vagy a frankofón jogokban az annak megfelelő Conseil d' Etat elkülönül a Legfelsôbb Bíróságtól (Kilic-Paksy, 2012:122-126).

A társadalom-gazdasági viszonyok egyre bonyolultabbá válása azonban szükségessé tette, hogy ez a két, egymástól élesen különbözô két irányzat közeledjen egymáshoz anélkül, hogy összecsúszásról szó lenne. Ez a folyamat megkezdôdött már a 19. század végén, és folytatódott az egész 20. század folyamán. Ez elôször a gazdasági élettel összefüggésben jelent meg, mivel rájöttek, hogy a gazdasági folyamatokat legalábbis indirekt módon befolyásolni, irányítani szükséges. Ezért az angolszász jogrendszerekben, elsôdlegesen az Adam Smith álláspontja uralta Angliában, ahol mindmáig a fố teoretikus nézet a „láthatatlan kéz” automatizmusa alapján, vagyis az önszabályozással irányított, liberalizált piac, a gazdasági életet és a szociális feszültségek megelőzése, kiiktatása, valamint a munkabéke érdekében egyre több normatív „act”-ot hoz meg az angol és az ír parlament, az USA-ban pedig a kongresszus. Ugyanakkor a kontinentális államokban az alapkódexek érintetlenül hagyásával egyre több olyan konkretizáló 
Prugberger Tamás: A jogalkotás és a jogalkalmazás torzulásának világjelensége...

törvényt hoznak, amely az alapkódex egyes rendelkezéseit a korviszonyoknak megfelelôen korszerúsíti. Ilyen célzatból egyre sûrûsödött a miniszterelnöki és a miniszteri rendeletalkotás. Ezen túlmenôen a bírói judikatúra az eseti ügyek elbírálása során egyre több olyan kiterjesztô vagy megszorító jogértelmezést végez, amely valamilyen formában összhangban áll az eredeti jogalkotói akarattal, elképzeléssel. E folyamat következtében egyre több elvi döntés és kollégiumi állásfoglalás születik a kontinentális jogrendszerhez tartozó államok legfelsôbb bíróságain, amelyek a jogszabályhoz hasonló, de mégsem vele azonos eredeti, hanem csak származtatott jogforrásként vehetôk számításba, és csak az alsóbb bíróságokra irányulnak. Ezektôl az alsóbb bíróságok elvben eltérhetnek ítélethozatalaik során, azonban az ilyen ítéletek tartalmát a jogorvoslat során eljáró magasabb szintú bíróságok módosítják, és összhangba hozzák az elvi döntésekkel és kollégiumi állásfoglalásokkal. A közigazgatási jogforrások tartalmát illetôen egyrészt hasonlóan járnak el az egyes ügyeket elbíráló közigazgatási bíróságok, a legfelsố közigazgatási bírósági szint pedig hasonló elvi állásfoglalásokat ad ki az alsóbb közigazgatási bíróságok számára.

Ezzel kapcsolatosan jegyzem meg, hogy újabban az Európai Parlament azt veti a közép- és a kelet-európai országok szemére, hogy a kormányzati irányítás befolyásolni tudja a közigazgatási bíróságokat. A magyar kormány válaszképpen sajnos nem állította fel a közigazgatási bírósági rendszert, pedig Németországban és más nyugat-európai államban, ahol közigazgatási bíróságok múködnek, ilyen kifogást az EU parlamentje nem tesz, holott a tervbe vett, önálló magyar közigazgatási bíróság szervezetileg a német közigazgatási bírák megválasztási rendszeréhez hasonló, független bírói testületi választási kautélák mellett szervezôdne. Érdemes lenne elgondolkodni a köztisztviselốk egzisztenciális biztonsága érdekében, hogy a beosztott köztisztviselốk közszolgálati viszonyaival kapcsolatos peres ügyekben, az olasz megoldáshoz hasonlóan, a munkaügyeket tárgyaló bíróságok járjanak el, és csak a vezetô köztisztviselốk ügyei tartozzanak a közigazgatási bíróságok hatáskörébe (Prugberger, 2015:30).

E természetes közeledési folyamatban bizonyos torzulás figyelhetô meg az Európai Bíróság és különösen az Európai Emberjogi Bíróság esetében, mivel mindkét bíróság a kontinentális európai jogállamok jogrendszerét a transzatlanti angolszász, vagyis az USA jogrendszeréhez nemcsak közelíteni, hanem ahhoz hasonlóvá kívánja alakítani. E folyamatnak a részleteit mind szervezeti, mind múködési viszonylatban Pokol Béla kutatta ki, kimutatva azokat a hagyományos és az ún. „természetjogi” elvekkel ellentétes torzulási folyamatokat, amelyek a jogalkotás és a jogalkalmazás statikai és funkcionális oldalán megmutatkoznak. Ami a kontinentális jogrendszer elveivel ellentétesnek és torzulásnak tûnik, az az igazságszolgáltatásban is érvényesüló, általánosan megengedett érdekérvényesítési rendszer, vagyis a lobbizás. Ez a kontinentális jogrendszerekben csak a törvényi és a rendeleti jogalkotásban elfogadott, amit arra létesített és testületi, illetve cégnyilvántartásba bejegyzett érdekvédelmi, érdekérvényesítố szervezetek folytatnak, amelyek jogosultak az érdekérvényesítô tevékenységük körébe tartozó témákban jogalkotást kezdeményezni a parlamentben képviselőik útján, valamint direkt módon is a kormányirányítás, emellett a minisztériumi szakközigazgatás legmagasabb fórumain, és ugyanígy a helyhatóságok szintjén is. Egyes államokban közvetlenül is felléphetnek, 
csatlakozva az egyes ügyeket elbíráló eseti ügyekhez. Erre Magyarországon is megvan a lehetôség valamennyi érdekvédelmi testület számára akkor, ha blankettaszerződéssel vagy más elôregyártott belsô szabályozással az azt kibocsátó, többnyire gazdasági szervezet sérti az érdekvédelmi testülethez tartozók általános érdekeit. Ha az állam követ el ilyet, és az az alkotmányban biztosított jogokat sérti, fennáll az Alkotmánybírósághoz való fordulás lehetôsége. Ugyanakkor vannak olyan államok is, ahol az országos érdekvédelmi szervezeteknek megvan a lehetôségük arra, hogy a rendes bírósági szervezet legfelsố fórumához forduljanak azzal a kéréssel, hogy az érdekvédelmi hatáskörükbe tartozó jogvitás ügytípusokban elvi állásfoglalást alkossanak. Magyarországon azonban az érdekvédelmi szervezetek számára ilyen lehetôség nem áll fenn. Ilyen lehetôség elsôsorban az USA egyes tagállamaiban van, miként több tagállamban alkotmányi elôírás az is, hogy a törvényalkotás, de ugyanígy a normatív rendeletalkotás során egyaránt vagy előzetesen ki kell kérni a szabályozás tárgyában érdekvédelmi kompetenciával rendelkezô országos szervezet, egyesület véleményét, sôt van, ahol előírás, hogy kívánságukra be kell vonni óket a szabályalkotási tevékenységbe.

Ehhez csak részben hasonló a helyzet ma már nemcsak egyes nyugat-európai, hanem közép- és kelet-európai államokban is, ahol három- vagy többoldalú érdekegyeztetés folyik állami részvétellel, országos érdekegyeztetési tanács keretében, amely jelenleg elsôsorban a munkaügyi és a társadalombiztosítási jogszabályok, esetleg a környezet- és a fogyasztóvédelmi normatív jogi előírások megalkotásánál áll fenn. Magyarországon ez a háromoldalú országos érdekegyeztési rendszer, Belgiumhoz és Hollandiához hasonlóan, az 1992. évi Munka törvénykönyve alapján érvényesült, és rövid ideig az Antall-Boross-kormány idején a társadalombiztosításnál is fennállt. Hasonlóan kezdett kialakulni a környezet- és a fogyasztóvédelem területén a környezetvédelmi és a fogyasztóvédelmi érdekvédelmi szervezetek bevonása a jogalkotásba, aminek eredményeként számos környezet- és fogyasztóvédelmi jogszabály és nevesített fogyasztóvédelmi ügylet megszületett, és bekerült a Ptk.-ba. Az érdekvédelmi szervezeteknek a jogalkotásba „ex lege” történó kötelezó bevonása azonban egyre zsugorodott. A munkáltatók és a szakszervezetek országos szövetségeinek, valamint a munkaügyi tárcának a részvételével az Országos Érdekegyeztetô/Munkaügyi Tanácsban megkötött tripartit megállapodás képezte alapját a leendô munkaügyi jogszabálynak egészen 2011-ig, mígnem e háromoldalú megállapodáson nyugvó jogalkotási folyamatot a 2011: XCIII. tv. meg nem szüntette. Az érdekegyeztetésen alapuló jogalkotási folyamat sajnos mára gyakorlatilag megszúnt, amibe belejátszott, hogy mind a jobboldalinak, mind pedig a baloldalinak elkönyvelt kormányok nem tárgyaltak egymással, ha pedig meg is állapodtak egymással az érdekvédelmi szervezetek és a kormány törvény-elôkészítô tárcájával, a tárca részérôl a megállapodás szerinti törvénybeterjesztést módosítási indítvány torpedózta meg.

A jogalkotásnak ez az új rendszere egyértelmúen lehetôséget ad a lobbizásnak és az informális érdekérvényesítésnek. Ez az új informális, lobbizásos kijáráson alapuló érdekérvényesítési rendszer az USA-ból indult el, ahol erre külön érdekérvényesítést végzô ügyvédi irodák szakosodnak. Ezek az irodák a normatív és egyedi döntések, aktusok meghozatalára feljogosított állami szerveknél járnak el megbízás alapján, va- 
Prugberger Tamás: A jogalkotás és a jogalkalmazás torzulásának világjelensége...

lamely szervezetten fellépő csoport, intézmény vagy vállalat érdekében, hogy a megcélzott állami intézmény a kívánságnak megfelelő normatív vagy eseti döntést, aktust a kívánt tartalommal meghozza, vagy egy korábbit ugyancsak a kívánt tartalommal megváltoztasson vagy hatályon kívül helyezzen, illetôleg visszavonjon. Ezzel az európai jogrendszerektôl teljesen idegen gyakorlattal szemben a már említettek szerint jogalkotásra vagy hivatalból, az arra feljogosított állami szerv saját elhatározása vagy valamely más hatósági szerv, vagy pedig a legfelsôbb bírósági fórumok, esetleg a jogi, igazgatási, közgazdasági, szociológiai és egyéb társadalomtudományi kutatásokat végzó egyetemek és kutatóintézetek kezdeményezése, jelzései alapján kerülhet sor. Ha pedig jogalkotásra sor kerül, be kell tartani a jogalkotásról szóló törvény elôzetes hatásvizsgálati eljárásra vonatkozó elốrásait annak érdekében, hogy a jogszabály a kívánt hatást el tudja-e érni, és milyen módon. Peschka Vilmos helytállóan írja le, hogy a pozitív jognak meg kell felelnie a társadalom objektív törvényeinek, a társadalmi többség objektív érdekeinek, mert ha ezeknek nem felel meg, akkor visszájára fordul. Vagy nem tartják be, vagy ha az állam erôszakosan betartatja, a betartatás diktatúrába és társadalmi ellenállásba csap át, amely közéleti feszültséget okoz (Peschka, 1979:164, 200; 1972:334; Prugberger, 2012).

Még szembetûnőbb a különbség a transzatlanti amerikai és az európai jogalkalmazás érdekpozicionálása között. Pokol Béla szerteágazó és mélyreható kutatásai azt mutatják, hogy az USA-ban, ahol a Legfelsôbb Bíróság egyúttal az alkotmánybíróság szerepét is betölti, a bírói joggyakorlat kiterjedhet a jogesetek elbírálása során azok alkotmányossági szempontból is történố minôsítésére is. Annálfogva pedig, hogy kevés a normatív aktus, jelentôsen elôtérbe kerül az eljáró bíróságok és bírák társadalom- és gazdaságpolitikai, valamint szociálpszichológiai meggyózôdése, szemlélete. Ezt a bírói, bírósági szemléletet igyekeznek a lobbisták, az érdekkijáró szervezetek és ügyvédi irodák a maguk javára alakítani, érzékenyíteni. Mindezt megteszik még az eljárás megindulása elôtt, az eljárás egész folyamatában, sốt az eljárás befejezését követôen, még az ítélet meghozatala elótt, ha pedig az ítélet kedvezôtlen, akkor ez a befolyásolás tovább folytatódik a jogorvoslati eljárás során (Pokol, 2017:30-36).

Ennek a pozitív jog normatív, jogdogmatikai és az általános etikai felfogással összhangban álló, objektív szemléletének az emocionális szubjektív színezetû egyoldalúvá tétele már tapasztalható a magyar judikatúrában is. Tipikus példája ennek a birtokháborítások rendezése. Az 1952. évi polgári eljárási törvény, majd pedig az 1959-ben hatályba lépett elsố magyar Ptk. felszámolta a birtokvédelmi ügyekben a bíróság elótt folyó ún. „sommás” birtokvédelmi eljárást, és azt a települési önkormányzat jegyzójének a hatáskörébe utalta. A jegyzók általában minden esetben a helyben lakók javára döntöttek az érzelmi alapon fennálló helyi összefonódások alapján, a nem helyben lakó sérelmet szenvedett hátrányára, akkor is, ha igaza volt. Korábban a bírósági keresettel elindult bírósági eljárásokban az ilyen ügyek jogszerúen lerendezôdtek. Mostanában viszont egyre több az olyan birtokháborítási ügy, ahol az „érzékenyített” bíróságok a jogszerútlenül eljáró birtokháborítónak adnak igazat szociális okokra hivatkozva. ${ }^{2} \mathrm{Ez}$ volt tapasztalható az Ajkai Timföldgyár tömegkatasztrófa okozása miatti büntetôügyében hozott felmentô ítéleteknél, ${ }^{3}$ amely szemlélet ma már egyre több polgári és bün- 
tetőügy elbírálásánál érezteti hatását. Azt pedig, hogy ez a kormányzati igazgatásban is érezhetô, mutatja Olaszország példája, ahol a lakosság többségének támogatását élvezô belügyminiszter által az olasz közrend és közbiztonság érdekében kiadott, a migránsokat jogtalanul szállító NGO-hajók kikötését tiltó rendelet hatálybalépését két másik miniszter humanitárius okokra hivatkozva megtorpedózta.

Mindez az USA érdekkijáráson alapuló közjogi döntéshozatali eljárási és bírósági joggyakorlata az Európai Gazdasági Közösség, jelenleg pedig Unió Bírósága, valamint az Európai Emberjogi Bíróság felállításával került át Európába. Európa nyugati felét a második világháborút követôen megszállt nyugati hatalmak közül az USA volt az, amely a legnagyobb befolyást gyakorolta Nyugat-Európa új berendezkedésének arculatára. Ebben az amerikai modell szerint felállított Európai Gazdasági Közösség (EGK), valamint az Európai Szabadkereskedelmi Társulás (EFTA) és a kettô keretei között kialakított bíróság, valamint a késôbb létrehozott Európai Emberjogi Bíróság ítélkezési gyakorlata játszotta és játssza mindvégig az európai nemzeti államok számára példát mutató közvetítô szerepet. Az EFTA-bíróság ítélkezési gyakorlata szinte egy az egyben megegyezett az EGK Bíróságának a gyakorlatával, miként múködésének a szabályai is az EGK direktíváival, irányelveivel és ajánlásaival. Az Európai Unió Bírósága, valamint az Európai Emberjogi Bíróság ítélkezési gyakorlata teljesen átvette az amerikai igazságszolgáltatási rendszer érdekkijárásos, a pozitív jogot háttérbe szorító, pillanatnyi vagy távlati politikai, gazdasági célokat figyelembe vevô érdekek szerint a jogi elveket teljesen parttalanul értelmezô és alkalmazó ítélkezési rendszerét. Ennek jogelméleti megfogalmazását tekintve, a harti jogfelfogást, hogy a jognak az általános etikai, erkölcsi elveknek kell megfelelnie, felváltotta a dworkini jogelmélet. Ezen, a neokantiánus iskola Jürgen Habermas által vezetett frankfurti irányzatának a kiforgatott álláspontja szerint a jognak nem az általános közerkölcsön és etikai elveken kell alapulnia, hanem a társadalom felsôbb, intellektuális rétege által vallott ún. diskurzus erkölcsén (Pokol, 2017:36-38). Ennek a szemléletnek megfelelóen épül fel és múködik mind az Európai Bíróság, mind pedig az Európai Emberjogi Bíróság.

A kontinentális európai jogalkotó hatóságok és bíróságok, szúkebben véve pedig a germán jogrendszerhez tartozó államok, így Magyarország jogalkotásra és ítélkezésre feljogosított állami mechanizmusa a Rudolph von Jhering által kialakított érdekösszhang megteremtésére igyekezett mindvégig és ma is alapozni mind a jogalkotási, mind pedig a jogalkalmazói tevékenységet (Jhering, 1904). Ezzel szemben a transzatlanti amerikai jogalkotásban és jogalkalmazásban az érdekküzdelem a domináns, és annak az érdekei szerint alakul egy kérdéses törvény megalkotása vagy annak tartalma, hogy az érdekeltek közül melyikük tudta, és milyen ügyesen vagy elszántsággal, direkt vagy indirekt jellegú lobbizással vagy másképpen a normatív aktust kibocsátó hatóságot, illetve az ítéletet megalkotó bíróságot sikeresebben befolyásolni. Miként Pokol Béla rámutat, az Európai Bíróság szervezete, amely az ügyek jogi szakmai tartalom szerinti felosztása szerint három eljáró bíróságból, az Európai Törvényszékbool, vagyis a Curiából, a Tribunalból, valamint az EU hivatalnokainak és alkalmazottainak az óket foglalkoztató uniós szerv között fennálló jogvitáiban eljáró bíróságból áll, egészen úgy épül fel, amely eme amerikai ítélkezési gyakorlatnak felel meg. A bírákat a tagállamok 
Prugberger Tamás: A jogalkotás és a jogalkalmazás torzulásának világjelensége...

delegálják, szolgálatuk meghatározott időre szól. Minthogy a bírák jelentős része nem a tagállamok felsô bíróságainak leülepedett szakmai és ítélkezési gyakorlattal rendelkezô bírái, hanem elméleti szakemberek, többnyire professzorok közül kerülnek ki, bizonyos időbe telik, hogy bíróként is éretté váljanak. Ezért a bírák túlnyomó része arra az ügyelókészító szakmai stábra szorul, amelynek feladata, hogy segítsen a bíráknak a hozzájuk kiszignált ügyek feldolgozásában, minôsítésében, az ítéleti koncepció kialakításában, annak megindokolásában, ideértve a megfeleló jogkövetkezmény (szankció) és mértékének a kiválasztását is. Ez a szakértói testület igyekszik az Európai Bizottság mindenkori jogpolitikai álláspontja szerint befolyást gyakorolni az elôadó bíróra; ha ez sikertelen, akkor a tanács elnökére és tagjára. A végsố kísérletet a bíróság elnöke teszi meg, aki közvetlenül az előadó bíróra, közvetve pedig a tanács elnökén keresztül próbál hatást gyakorolni az elôadó bíróra. Az álláspontján változtatni nem akaró előadó bíró lecserélésének kérésére a bíróság elnöke felkérheti a tanácselnököt, aki viszont saját elhatározásából is fordulhat ilyen kérelemmel a bíróság elnökéhez. Minthogy az ügyeket elókészítő szakmai stáb sztenderd és jól bejáratott az Európai Bíróság múködésében, az újonnan érkezett bírák teljesen, de a régebbiek is jelentôs részben rájuk támaszkodnak, még akkor is, ha a francia nyelvet tökéletesen bírják, mivel a bíróság belsố használatú francia ítélkezési és munkanyelve - miként erre Pokol Béla utal - sajátos, „házon belüli” francia. Eme ügyelókészítô stáb szakjogászai relatív módon úgy állandóak, hogy időszakosan felváltva egyszer a bizottság jogi apparátusában, más idószakban pedig a bíróságnál dolgoznak. Ennélfogva szoros az átjárás a bíróság és az Unió jogászi stábja között. Bár minden bírónak joga van a saját hazájából ügyelôkészítő szakértôt hozni, Pokol Béla szerint azonban azok éppúgy kiszolgáltatottak, mint a bírák, a már említett okok miatt. Ezenkívül a bírák jogi meggyôzódését jelentősen befolyásolják, ítélkezési szabadságukat indirekt módon nagymértékben korlátozzák a fôtanácsnokoknak az ítélkezés elôtt már jóval korábban átadott állásfoglalásai (Pokol, 2019:51-77). A bírói függetlenség tehát áttételesen és indirekt módon a bíróság szervezeti felépítésén és múködési mechanizmusán keresztül nagymértékú befolyásoltság alatt áll, és ezáltal észrevehetôen sérül.

Nagymértékú az Európai Emberi Jogi Bíróság (EJEB) esetében a bírói függetlenség korlátozása, ami közvetlen formában, a bíróság szervezetébe beépítve valósul meg. Az egyfokú ítélkezés alapja az ENSZ Emberi Jogok Egyetemes Nyilatkozata, és az Európai Unió Alapjogi Chartája. Ezek alapján az EJEB kialakította a maga esetjogát, lényegében az angol bíráskodás mintáját alapul véve, azzal azonban, hogy az ügyet elôkészító bíró nem a saját meggyôzôdése alapján választja ki az esetjogból azt, amit alapul véve, a meggyôződése szerint az ítéleti álláspontját megalapozza, hanem szigorúan meghatározták, mennyiben lehet eltérni a zsinórmértékül szolgáló esetjogtól. A bírák tevékenységét itt is egy központosított jogászapparátus segíti, miként az Európai Bíróságnál. Különbség azonban abban van, hogy itt - miként ez Pokol Béla kutatásaiból kitûnik - a segítő szakértőt az ügyet előkészítő elôadó bíró részére az EJEB elnöke választja ki a központi szakértői csoportból. A szakértői apparátusban dolgozó „registry lawyerek” alkalmazásuk kezdetén ideiglenes jelleggel, négyéves időtartamra nyernek felvételt, és azután döntenek a véglegesítésükrôl. Ezért lojálisak az 
EJEB felsô vezetéséhez. Ha a kiküldött registry lawyer nem tudja meggyôzni a másként gondolkodó ügyelőkészítô elôadó bírót vagy az ügyben eljáró kamarát, akkor az EJEB elnökéből és a szekcióvezető bírákból álló „jurisconsult” végsô soron elveheti az ügyet az elôadó bírótól vagy az ügyben eljáró kamarától is, és más elóadó bírót jelöl ki a kamarának, vagy más kamarának adja át az ügyet tárgyalásra. Ezenkívül, mielôtt az ügy döntésre a kamara elé kerülne, a jurisconsult apparátusa részéról van egy apparátuskontroll is, amely a jurisconsult megbízásából minden egyes ügy tervezetét hivatalból ellenôrzi, és ha lényeges eltérést tapasztal az esetjogtól, felhívja az előadó bírót és a segítô jogászteamet, hogy szüntessék meg az eltérést. Ha ezt nem vagy nem megfelelően teszik meg, a heti rendszerességgel tartott tájékoztatókon ezt minden bíró és registry lawyer tudomására hozza a jurisconsult (Pokol, 2019:39-50). Ilyen eltérés lehetett volna például, ha annak a panasszal élố magyar állampolgárnak az ügyében, aki nyilvánosan vörös csillagot viselt a kabátja gallérján, az EJEB ügyet elókészítô bírája megállapította volna, hogy jogerôsen ítélték el, mivel Magyarországon a vörös csillag, a horogkereszthez hasonlóan, önkényuralmi jelvénynek számít (Bárd, 2012:149-151). Mindebbôl látható, hogy az EJEB jogalkalmazási gyakorlata során, torzítva a bírói függetlenséget, az ítéletet tulajdonképpen a „registry lawyer” és a „jurisconsult" apparátusa hozza meg. ${ }^{4}$

Mindaz, amit Pokol Béla Az európai jurisztokrácia címú könyvében e két bíróságról és mindkettő ítélkezési gyakorlatának visszásságairól leír, más nyugat-európai kutatók empirikus kutatásaival egyezik, kiknek állításait részletesen hivatkozza és ismerteti. ${ }^{5}$ Rámutat továbbá arra is, hogy a két bíróság az így kialakított és irányított ítélkezési gyakorlatán keresztül, voluntarisztikus módon a nemzetközi jogot „alkotmányjogiasítja”, az egyes európai államok alkotmánybíróságain keresztül pedig az EJEB és az Európai Bíróság gyakorlatán keresztül módosíttatja azok alkotmányát, alaptörvényét. Azzal viszont, hogy az Európai Bizottság és az Európai Bíróság között milyen szoros kapcsolat áll fenn, a bizottság nyilvánvalóan befolyással lehet az Európai Bíróságra, hogy politikai érdekeinek megfelelően milyen irányelv meghozatalára, az irányelvek milyen jellegú módosítására tegyen javaslatot, amelyet aztán az Európai Parlament elé visz (Pokol, 2019:57-61). Ennek az eredményeként tapasztalható tendencia, hogy az EU újabb irányelveinél és módosításainál a nemzeti sajátosságok szerinti szabályozásnak megengedett keretek egyre szúkülnek, ezáltal az irányelvek is egyre inkább a tagállamokra változtatást nem megengedó, kötelezô direktíváihoz kezdenek hasonlítani. ${ }^{6}$ Emellett az USA-ban koncentrálódott globális pénzügyi és gazdasági nagyhatalom NGO-hálózata által jelenleg még csak az igazságügyi jogszolgáltatás szereplői irányában végez „érzékenyítő tanfolyamokat”, amelyeknek célzott alanyai bírák, ügyészek és ügyvédek (Prugberger, 2018:110-113, 124-127). Eme érzékenyítő tanfolyamoknak a hatása már érezhetố az igazságszolgáltatásban, ahol váratlan fordulatok alapján olyan nem várt ítéletek születnek mind büntetô-, mind pedig polgári ügyekben, ahol az érdekösszhang megteremtésére irányuló, helyes jogértelmezéssel szemben a pozitív jogot a bizonyos érdekek szerint történô formálása jellemzi. Egyúttal az ilyen ítéletek válnak azután olyan esetjoggá, amelyeket a bíróságoknak követniük kell. Egyes nyugat-európai államok - mindenekelótt Németország és a skandináv 
Prugberger Tamás: A jogalkotás és a jogalkalmazás torzulásának világjelensége...

államok - élen járnak ebben, mások, különösen a közép- és a kelet-európai államok, igyekeznek ellenállni e hatásoknak. Magyarország is ez utóbbi államok körébe tartozik. Ugyanakkor némely kérdésben hasonló módszereket alkalmaz, mint amit az EU és a Bizottság. Különbség csak az elérni kívánt célokban van, ami azonban nem mellékes.

Mint már arról szó esett, az angolszász esetjogban, ha nincs normatív aktus, akkor a bíró a saját jogi belátása alapján dönt, amit csak a történelmileg kialakult bírói esetjog befolyásol. Az angol bírónál az „érzékenyítésnek” azt kell elérnie, hogy az elbírálása alatt álló ügyhöz tartozó „ítéletelôzményeket” az érzékenyítésnek megfelelóen vizsgálja, és közülük mintának az érzékenyítésnek megfelelốt válassza ki. Mivel - mint láttuk - az USA bíráit ilyen ítélkezéstörténeti elôzmények nem kötik, érzékenyítésre nincs szükség, helyét átveszi a direkt lobbizás.

Más a helyzet a kontinentális jogrendszereknél. A skandináv jogrendszereknél, ahol a bírói gyakorlatot nem mindenütt fedi le a pozitív jog, és ezért sok területen a kodifikálatlan szokásjog uralkodik, az érzékenyítés a bíró lelkiismeretét és jogtudatát célozza meg, hogy az abban foglaltak szerint hozza meg a döntését az adott ügycsoportokban. A kontinentális Európa nyugati, déli és középsố, sốt még a keleti területein a frankofón-latin és a germán jogrendszer uralkodik, ahol a bíró által alkalmazandó jog kodifikált pozitív, azaz tételes jog. Ezért a bíró a törvény által elôírtakhoz kötött. A kettố között azonban mégis van különbség: ugyanis a frankofón-latin tételesjog-alkotás jóval elnagyoltabb, mint a precízebb, sốt néha túlszabályozott germán jogalkotás, emellett a frankofón-latin jogalkotás ritkábban novelláz, mint a germán, ezért nagyobb tere van a bírónak arra, hogy az idóközi körülményváltozások figyelembevételével a germánnál tágabban alkalmazza a kiterjesztô vagy megszorító jogértelmezést, valamint szélesebb körben alkalmazzon analógiát. A germán jogrendszerekben általában az „analogia legis”, a törvényi analógia a megengedett, a frankofón-latin jogrendszerekben viszont az analógia iuris, vagyis a joganalógia is, sốt a svájci Ptk. preambuluma kimondja, hogy ha a bíró az analógia alkalmazására még jogelvet sem talál, akkor a „jogászi lelkiismerete” szerint hozhatja meg az ítéletet. A túlnyomóan germán svájci jog e tekintetben kantonjainak nemzetiségi összetétele folytán francia és olasz befolyás alatt is áll. Mindezt figyelembe véve, az érzékenyítés a frankofón-latin államoknál könynyebben megy, mint a germán államoknál, kivéve a svájci jogban csak nagyon ritkán jelentkezô abszolút joghézagot. Mindenesetre a bírói gyakorlat nagymértékben függ attól, hogy milyen a pozitív jog. Az „érzékenyítés” sikere a német bíráknál nagymértékben attól függ, hogy az általuk alkalmazásra kerülő tételes joggal összhangban áll-e az érzékenyítés jogpolitikai jellege, mivel a német jogalkalmazó tiszteletben tartja a jogalkotást, és nehezen bírható rá, hogy a pozitív jogtól eltérjen. Nem véletlen, hogy az európai ember jogi és az uniós bíráskodás az európai jogalkotást, az pedig a tagállami jogalkotást célozta meg.

Az uniós normaalkotás menetét vizsgálva, az Európai Unió bizottsága, kikerülve a szociális partnerekkel való valódi érdekegyeztetést, az Európai Bíróságnak és az EJEB-nek megfogalmazza az európai jogi normatervezetet, direktíva- és irányelvjavaslatot, amelyet átküld az európai érdekegyeztetési fórumnak, amelyben az Európai 
Szakszervezeti Szövetsége (ETUC), az Európai Gyáriparosok és Munkáltatók Európai Szövetsége (UNICE), valamint az Állami Vállalatok Európai Központja (CEEP) foglalnak helyet. E fórumon az utóbbi kettő „egy húron pendül”, és le tudja szorítani a munkavállalók és az önfoglalkoztatók, azaz a kényszervállalkozók és az egyéb módon foglalkoztatottak szociális érdekeit. Az ilyen okok miatt túlnyomóan munkáltatói érdekeket tükrözô tripartit megállapodás, vagy a bizottsággal összhangban álló két álláspont egy ellenében kerül vissza a bizottsághoz, ami alapján a bizottság elkészíti a tervezetet, amit a parlament az eddigi gyakorlat alapján megszavaz. Más kérdésekben, így az élelmezésügyi, a környezetvédelmi és a fogyasztóvédelmi kérdésekben, hasonló fórum hiányában, a bizottság elốzetesen csak az ENSZ szakosított szerveit kérdezheti meg, amely azonban számos kérdésben egyoldalú véleményformálás lehet. Ez különösen a fogyasztóvédelem és a környezetvédelem területén mutatkozik meg. A fogyasztóvédelem területén például abban, hogy a fogyasztói hitelrôl szóló irányelv-módosítások a bankok javára csökkentették a fogyasztói hitelt felvevók speciális kedvezményeit, zsugorítva a fogyasztói hitel körét, és hasonló módosítások történtek a kereskedôk előnyére és a fogyasztók hátrányára az üzlethelyiségen (árudán) kívül történô, házaló és elektronikus kereskedelemre vonatkozó irányelvi elôírások esetében (Prugberger, 2009). ${ }^{7}$ Ami pedig a környezetvédelmet illeti, Bándi Gyula mutatott rá helytállóan az akadémiai doktori értekezésében, hogy az EU politikájában és normaalkotásában hasonlóan marginális a környezetvédelem, mint a magyar politikában és jogalkotásban, ami megmutatkozik az erdó-állagvédelem és az erdôgazdálkodás felügyeletének elhanyagolásában. Azonban nem szabad figyelmen kívül hagyni, hogy a jelenlegi kormány a villamos energia esetében nem a természetromboló vízlépcsőrendszerrel kívánja a szükséges energiát megtermelni, hanem atomerômúvének korszerúsített bővítésével. Ezzel szemben az EU és a nyugat-európai államok többsége a tájromboló vízlépcsôs és a madarakra veszélyes szélturbinás rendszert helyezi előtérbe, holott kimutatták, hogy az atomreaktorral történô energiatermelés biztonságos és szennyezéstôl mentes. Ennek ellenére a bizottság igyekezett gátolni a magyar atomerômú-fejlesztést, holott az olajlobbi letörése mellett, a benzin és gáz hajtotta gépjármúvek elektrifikálásra történô gyors átállítását kellene direktívaalkotással megvalósítani, mivel a szén-dioxid-kibocsátás legfóbb felelôse a gépjármúforgalom.

Ahogy korábban utaltam rá, a magyarországi jogalkotási gyakorlatból és magából a törvényból is kikerült a valódi érdekegyeztetés rendszere. Az 1992. és az 1993. évi munka- és közszolgálati jogalkotás az Országos Érdekegyeztetési Tanács létesítésével kialakította az országos érdekegyeztetés általános rendszerét, amely azonban nem felelt meg az egyenlő elbíráláson alapuló, paritásos érdekképviselet rendszerének. E munka- és közszolgálati jogi jogalkotási csomagban nem történt meg a regionális általános és az országos, valamint a területi ágazati érdekegyeztetés rendezése. Ez a jelentôs méretû joghézag csak az országos érdekegyeztetésrôl szóló 2009. évi LXXIII. tv. és az ágazati, valamint a területi érdekegyeztetésról megalkotott 2009. évi LXXIV. tv.-vel szünt meg. Ez országos általános, illetve ágazati és területi szinten is, a holland érdekegyeztetési rendszerhez hasonlóan, paritásos képviselettel lehe- 
Prugberger Tamás: A jogalkotás és a jogalkalmazás torzulásának világjelensége...

tôvé tette az állam által tervbe vett jogalkotás tartalmában a szociális partnereknek a jogalkotóval történô előzetes megállapodását. Mint már jeleztem, ezt a 2011. évi XCIII. tv. az országos érdekegyeztetés vonatkozásában megszüntette azzal, hogy az OÉT megállapodáskötési jogkörét megszüntetve, e fórumot a többi érdekképviseleti társadalmi szervezettel, a kamarákkal és az egyházi szervezetekkel kibôvítve csak konzultatív és javaslattevô fórummá tette. Helyesebb lett volna e kibóvített tanácson, vagyis a Nemzeti Gazdasági és Társadalmi Tanácson (NGTT) belül kialakítani azokat a szakmai érdekegyeztetố tanácsokat, amelyekben állami részvétellel megállapodáskötésre is kiható, érdemi érdekegyeztetés folyhatna. Ez az előzetes állami részvételú megállapodáskötési lehetôséggel felruházott, országos általános és ágazati-szakmai érdekegyeztetési rendszer kiterjedhetne nemcsak a jogalkotási tervezetekre, hanem az azon a területen folyó közigazgatási jogalkalmazási gyakorlat irányvonalának a meghatározására is.

Összegezve az eddigieket, a leírt körkép alapján megállapítható, hogy mind a klasszikus európai angolszász jogban, mind pedig a kontinentális frankofón-latin és a germán jogrendszerekben a jogalkotás, de fôleg a jogalkalmazás területén erôs torzulások következtek be. Ennek kiinduló tényezóje az USA jogrendszere, amely az egoista érdekek küzdelmének folyamatát tág keretek között meghatározott normarendszeren belül elismeri. Az USA demokrata párti irányvonalának az alapvetô realista természetjogi elveken túllépó politikája a maga céljai szerint igyekszik befolyásolni a bírói gyakorlatot, és az annak hatására történô kisszámú, de a folyamatokat annál erôteljesebben meghatározó normatív aktushozatalt. A jognak ezt a bírói gyakorlaton és aktushozatali tevékenységen alapuló funkcionálását elsôdlegesen széles körú szabadkereskedelmi társulási megállapodások, egyéb nemzetközi egyezményeknek az államokra történố rákényszerítése, ezeknek a nemzetközi jogi jellegét az alkotmánybíráskodáson keresztül közjogivá alakítása, valamint egyes korábbi egyezmények formális hatályon kívül helyezése nélkül történő félretétele, mintegy lomtárba helyezése útján alakítja. Ezt a demokrata párti folyamatot az USA-ban sikeresen tudta mérsékelni a Trump elnöklete alatt folyó republikánus politika, amely nem a láthatatlan globális gazdasági és pénzügyi hatalmat, hanem az országa polgárai számára kedvezó középosztályt kívánja helyzetbe hozni. Az EJEB és az EU jogi tevékenységében azonban még mindig erôs az USA korábbi demokrata párti politikájának a hatása. Ez különösen a bevándorlás kérdésének jogi megítélésében nyilvánul meg. Az EU Bizottság nem alkalmazta a schengeni egyezményben lefektetett, külsô határvédelmi elôírásokat, és jelentôs mértékben segélyezi a dolgozni kevéssé akaró, inkább a segélyekból megélni akaró, muszlim bevándorlók tömegét. A sokszor deviáns magatartásuk miatt velük szemben induló büntetô- és polgári bírósági eljárásokban az EU bírósága és az EJEB is a „kedvezố elbánást” igényli. Ezt a mindenkori hatalommal szemben aulikusan lojális német bírói gyakorlat nagy többségében teljesíti, a frankofón-latin bírói gyakorlatban azonban a belülrôl is kiinduló bírói függetlenség következtében aszerint oszlik meg, hogy milyen a bíró világnézete és jogi felfogása. A jognak ez az erodálása áttételesen a jogalkotási és jogalkalmazási érdekösszhang megvalósításának a területén érződik. 


\section{Polgári Szemle · 15. évfolyam 4-6. szám}

\section{JEGYZETEK}

1 Peschka Savignynek ad igazat Thibaut német kodifikációs törekvéseivel szemben, mondván, hogy Németország még nem érett meg rá.

2 Általánosságban lásd Pokol, 2017:38-42; birtokháborítási ügyben Sárvári Járásbíróság, 2. I. 20.574/2015/2. sz. elsôfokú ítélete, fellebbviteli eljárás során Szombathelyi Törvényszék 12. Pf. 20.562/2017/5.II., Ellenük alk. jogi panasz, IV. 1908/2018. (A.B.). Tényállás: öröklés alapján felperes és alperes írásbeli szerzôdéssel megállapodtak a közös ingatlan birtoklásának módjában, amit alperes nem tartott be. Mivel alperes bent lakott, felperes viszont csak idôszakosan, a jogi elôírásoktól eltérô, szociálisnak mondható jogértelmezéssel utasította el a felperesi keresetet, jogosnak tartva a jegyzó által megállapított, helyi öszszefonódástól sem mentes birtokháborítást.

3 (6) Bíróság.hu/Törvényszékek/Veszprémi Törvényszék/Sajtóközlemény. Ítélet a „Vörösiszap-katasztrófával" kapcsolatos büntetôügyben. 2016. január 28. Ezt a Gyôri Ítélôtábla a fellebbezés során hatályon kívül helyezte azzal, hogy az új eljárásra másik bíróságot jelöl ki. 2017. márc. 13. Az elsôfokú ítélet jogi értékeléséhez lásd Prugberger, 2017.

4 Ez részben vonatkozik az Európai Bíróságra is, teljesen azonban az EJEB-re.

5 Azokban a témákban, amelyeknél Pokol Bélának itt feldolgozott két könyvére hivatkoztunk, mindegyik tétele eredeti forrásokkal, valamint nyugat-európai és transzatlanti kutatók kutatási eredményeivel alátámasztott (lásd Pokol, 2017 és 2019 lábjegyzetanyagai).

6 Prof. Peter Bülow (Uni. Trier) a Debreceni Egyetem Közgazdasági Karán, prof. Markus Artz (Uni. Bielefeld) a Miskolci Egyetem Jogi Karán tartott elôadásában szólt arról, hogy az üzlethelyiségen kívül kötött szerzôdésekrôl szóló 98/27. sz. irányelv helyébe lépó 2009/22. sz. EK. irányelv a fogyasztók hátrányára majdnem direktíva jelleggel novellázott, és ugyanez történt a fogyasztói hitelrôl szóló 7/102. s. EGK irányelvnek a 2009/22. sz. irányelvvel történt felcserélésénél is, mely szúkítette a fogyasztói hitel alkalmazhatóságát. Ez Magyarországon a devizahiteleseket hozta igen hátrányos helyzetbe.

7 Hasonlóként utalnak a szociális minimumstandardok szúkítésére Az európai munkajog vázlata 2007. évi 1. kiadása és 2016. évi 2. kiadása közti idôszak irányelv-módosításai (Prugberger-Jakab-Zaccaria, 2016).

\section{FELHASZNÁLT IRODALOM}

Badó Attila (2012): Az angol jog vázlata. In: Badó Attila et al. (szerk.): A jogrendszerek világa. Pro Talentis Universitatis Alapítvány, Szeged.

Badó Attila - Bóka János (2012): Az Egyesült Államok jogrendszere. In: Badó Attila et al. (szerk.): A jogrendszerek világa. Pro Talentis Universitatis Alapítvány, Szeged, 77-85.

Bárd Petra (2012): Strasbourg kontra Magyarország, avagy az Emberi Jogi Egyezmény esete a magyar jogrenddel a Fratanoló ügy kapcsán. Kriminológiai Közlemények, 71. sz., 145-204.

David, René (1977): A jelenkor nagy jogrendszerei. Közgazdasági és Jogi Könyvkiadó, Budapest.

Eörsi Gyula (1975): Összehasonlító polgári jog. Jogtípusok, jogcsoportok és a jogfejlôdés útjai. Akadémiai Kiadó, Budapest.

Horváth Pál - Kahler Frigyes - Révész Tamás - Stipta István - Zlinszky János (é.n.): Általános jogtörténet I-II. ELTE, Budapest.

Jhering, Rudolph von (1904): Der Zweck im Recht. 4. Aufl. Verlag Breitkopf \& Hartl, Leipzig.

Kilic Keziban - Paksy Máté (2012): A francia jogrend. In: Badó Attila et al. (szerk.): A jogrendszerek világa. Pro Talentis Universitatis Alapítvány, Szeged, 114-126.

Mezei Péter (2012): A német jogrendszer alapjai. In: Badó Attila et al. (szerk.): A jogrendszerek világa. Pro Talentis Universitatis Alapítvány, Szeged, 129-151.

Niederhauser Emil (1965): A parasztság Európában. In: Szabó István (szerk.): A parasztság Magyarországon a kapitalizmus korában 1848-1914. II. Akadémiai Kiadó, Budapest, 655-692.

Peschka Vilmos (1972): A modern jogfilozófia alapproblémái. Gondolat Kiadó, Budapest.

Peschka Vilmos (1975): Max Weber jogszociológiája. Akadémiai Kiadó, Budapest. 


\section{Prugberger Tamás: A jogalkotás és a jogalkalmazás torzulásának világjelensége...}

Peschka Vilmos (1979): A jogszabályok elmélete. Akadémiai Kiadó, Budapest.

Peschka Vilmos (1980): Thibaut és Savigny vitája. In: Peschka Vilmos: Jog és jogfilozófia. Közgazdasági és Jogi Könyvkiadó, Budapest.

Pokol Béla (2017): A jurisztokratikus állam. Dialóg Campus Kiadó, Budapest.

Pokol Béla (2019): Az európai jurisztokrácia. Dialóg Campus Kiadó, Budapest.

Prugberger Tamás (1978): A gazdasági szervezetek szabályozásának jogrendszertani kérdései, különös tekintettel a szövetkezeti és az agrárviszonyokra. Szövetkezeti Kutató Intézet, Közlemények 133., Budapest.

Prugberger Tamás (2009): Az európai uniós munkajogi szabályozás módosulásának és kiegészítésének kihatása a munkavállalók szociális érdekeire. Európai Jog, 9. évf., 4. sz., 20-27.

Prugberger Tamás (2012): A jogi normák a természeti és a társadalmi törvényszerúségek összefüggésrendszerében. Publicationes Universitatis Miskolcinensis, Sectio Iuridica et Politica, 30. évf., 1. sz., 125-145.

Prugberger Tamás (2015): A munka-, a közszolgálati és a társadalombiztosítási szakbíráskodás tervezett átalakításának terve a közszolgálati jogviták elkülönítésén keresztül. Magyar Jog, 62. évf., 1. sz., $27-34$.

Prugberger Tamás (2017): Az iszapkatasztrófa büntetôügyének fonákságai. Magyar Idôk, február 2., www. magyaridok.hu/velemeny/az-iszapkatasztrofa-buntetougyenek-fonaksagai-1407070/.

Prugberger Tamás (2018): Az Európába irányuló tömeges migráció etnográfiai, gazdasági, szociális, kulturális és jogkövetkezményekkel járó hatásai. In: Szalma József (szerk.): A Magyar Tudomány Napja a Délvidéken 2017. Vajdasági Magyar Tudományos Társaság, Újvidék.

Prugberger Tamás (2019): A többletmunkavégzés korlátainak liberalizálásával összefüggó jogi, ergonómiai, család- és népességpolitikai problémák. Új Magyar Közigazgatás, 12. évf., 2. sz., 110-116.

Prugberger Tamás - Jakab Nóra - Zaccaria Márton L. (2016): Az európai munkajog vázlata. Abriss des europaische Arbeitsrechtes. 2. kiadás, Novotni Kiadó - Lícium Art Kiadó, Miskolc-Debrecen (2. kiadás 2016).

Prugberger Tamás - Tóth Hilda (2019): A 2012. évi Munka törvénykönyvének egy újabb módosítása a rendkívüli munkavégzés korlátainak tágítása érdekében. Jogtudományi Közlöny, 74. évf., 1. sz., 25-30.

Radics Olivia - Bencze Mátyás (2012): A common law Anglián kívüli változatai. In: Badó Attila et al. (szerk.): A jogrendszerek világa. Pro Talentis Universitatis Alapítvány, Szeged, 56-60. 